DOI: $10.46730 /$ japs.v2i1.14

\title{
Peran Daerah Dalam Mengimplementasikan Program Sebagai Upaya Perlindungan Tindak Kekerasan Terhadap Anak Di Kabupaten Karimun Dalam Mewujukan Kota Layak Anak
}

\author{
Indrawan, Deska Zulkarnain ${ }^{1}$ \\ ${ }^{1}$ Universitas Karimun. \\ Email : indrawan.up@gmail.com,deskaalhaqi@gmail.com
}

\section{Kata kunci}

Keywords

Peran,Kekerasan

Terhadapa Anak,

Langkah Strategis

\begin{abstract}
Abstrak
Anak merupakan aset sekaligus generasi penerus bangsa, sudah seharusnya pemerintah daerah mengambil langkah Stategis untuk memenuhi perlindungan anak yang berkelanjutan. Pemerintah daerah sebagai perwakilan pemerintah yang pertama kali bersentuhan lansung dengan anak, harusnya mempunyai langkah Strategis yang langsung menyentuh akar persoalan terhadap anak, konsep pemenuhan perlindungan anak yang berkelanjutan oleh pemerintah daerah. Perlindungan anak ini merupakan bagian dari yang tidak terpisahkan didalam konstitutional Indonesia pun hal ini jelas diutarakan, jangan sampai dengan lemahnya perlindungan anak, akan membawa dampak kehancuran bagi kemajuan dan perkembangan bangsa Indonesia. Karena bangsa ini kedepannya terletak di tangan seorang anak-anak indonesia.
\end{abstract}

\begin{abstract}
Children are assets as well as the nation's future generation, the local government should take strategic steps to fulfill sustainable child protection. The local government as the government's representative for the first time having direct contact with children, should have strategic steps that directly address the root of the problem for children, the concept of fulfilling sustainable child protection by the local government. Child protection is an inseparable part of the Indonesian constitution and this is clearly stated, lest weak child protection will have a devastating impact on the progress and development of the Indonesian nation. Because this nation in the future lies in the hands of Indonesian children.
\end{abstract}

\section{Pendahuluan}

Kompleksitas permasalahan perlindungan anak di Indonesia yang semakin meningkat secara kualitas maupun kuantitas yang melibatkan anak, orang tua, maupun penyelanggaran belum sepenuhnya tertangani secara kelembagaan. kasus yang terjadi kepada anak merupakan suatu fenomena yang menjadi perbincangan 
akhir-akhir ini dibeberapa daerah, tidak terkecuali karimun terkait perihal pengebrekan di perumahan villa yang melibatkan anak di bawah umur untuk di jadikan jasa layanan on line dengan para pelanggan yang beroperasi secara ilegal, hampir setiap hari di muat di seluruh media. Hal ini begitu ironi memang, dimana dari hari ke hari, kasus kekerasan terhadap anak semakin meningkat dan mengkhawatirkan dan parahnya kekerasan seksual sebagai kasus yang kerap muncul di tengah-tengah masyarakat disamping kekerasan fisik. Anak dengan mudah menjadi korban kekerasan karena berada pada posisi yang lemah. Selain lemah fisik, kepolosan dan keluguan pada anak semakin memuluskan jalan pelaku untuk melancarkan aksinya sehingga banyak anak yang menjadi korban. Saat ini kekerasan anak di Indonesia cukup tinggi dan bahkan riilnya jumlah kasus tersebut lebih banyak daripada yang terungkap ke permukaan. Hal itu karena masih banyak orang tua yang tak mau melaporkan kasus kekerasan yang dialami oleh anaknya pada pihak yang berwajib atau lembaga perlindungan anak, karena malu dan menganggap hal itu adalah aib keluarga.

Dalam kacamata sosial penyebab kekerasan pada anak tersebut memang sangat rumit mulai dari segi sosial ekonomi, sosial budaya hingga pendidikan. Kekerasan identik dengan penganiayaan fisik seperti pemukulan dan pemerkosaan, tetapi pada kenyataannya kekerasan bukan hanya berupa penganiayaan fisik saja, melainkan berupa kekerasan mental (psikis). Luka yang seumur hidup akan terus di sandang si anak yang mungkin hanya bisa di lupakan tetapi tidak akan pernah hilang dalam ingatannya.

Adak banyak faktor terjadinya kekerasan terhadap anak. Secara garis besar kekerasan terjadi akibat semakin lemahnya perhatian serta kurangnya peran masyarakat (baik perseorangan, lembaga perlindungan anak, lembaga kesejahteraan sosial, organisasi kemasyarakatan, lembaga pendidikan), kurangnya ketersediaan sarana dan prasarana. Banyak dijumpai fenomena dalam suatu keluarga, misalnya saja anggota keluarga yang memiliki kekuasaan dan kekuatan cenderung bertindak eksploitatif terhadap anggota keluarga yang lain. Bila dalam lingkungan keluarga saja tidak tercipta rasa nyaman dan aman, hal ini akan memicu tindakan yang bisa saja kurang baik dalam pergaulannya seperti halnya kekerasan terhadap teman sebaya ataupun umur dibawahnya.

Untuk mencegah terjadinya hal yang tidak diharapkan maka diperlukan dengan menciptakan suasana kondusif untuk tumbuh kembang Anak, sehingga anak tumbuh sesuai dengan haknya dan sesuai dengan tahap perkembangannya.

Anak adalah asset "Produktif" bagi keluarga dan masyarakat Anak juga diakui sebagai komunitas yang diklaim sebagai penerus bangsa estafet perjuangan dalam masyarkat. Jaminan ini dikuatkan melalui ratifikasi konvensi internasional tentang Hak Anak, yaitu pengesahan Konvensi Hak Anak melalui Keputusan Presiden Nomor 36 Tahun 1990 tentang Pengesahan Convention On The Rights Of The Child (Konvensi 
Tentang Hak-Hak Anak) ${ }^{1}$. Negara, Pemerintah, Pemerintah Daerah, Masyarakat, Keluarga dan Orang Tua berkewajiban untuk memberikan perlindungan dan menjamin terpenuhinya hak asasi Anak sesuai dengan tugas dan tanggung jawabnya mengingat betapa pentingnya anak, terlepas baik itu sebagai korban maupun pelaku dan lemahnya posisi anak sehingga dunia dan negara wajib memberi perlindungan khusus pada anak.

Komitmen tersebut bukan hanya termaktub dalam undang-undang semata, namun secara eksplisit tercantum dalam Undang- Undang Dasar Negara Republik Indonesia Tahun 1945. Konstitusi juga memberikan atensi besar terhadap perlindungan anak dari kekerasan. Pasal 28 B ayat (2) menegaskan bahwa "Setiap anak berhak atas kelangsungan hidup, tumbuh, dan berkembang serta berhak atas perlindungan dari kekerasan dan diskriminasi". Menurut konstitusi tersebut, negara memastikan tak boleh ada anak dimanapun berada tidak mendapat perlindungan Di pihak lain, negara juga tak mengizinkan anak-anak mendapat kekerasan dalam bentuk apapun

Dari banyaknya kasus kekerasan pada anak yang terjadi menunjukkan kurangnya perlindungan dan peran yang sesungguhnya dari Pemerintah terhadap warga negara, khususnya anak yang posisinya sangat rawan dan lemah untuk dijadikan obyek kekerasan. Kekerasan merupakan masalah bersama. Pemerintah dan masyarakat bertanggung jawab untuk melindungi dan menangani kasus kekerasan serta menjaga agar tidak ada tindak kekerasan. Undang-undang tentang perlindungan anak harus membutuhkan langkah konkret atau strategi yang benar-benar menyentuh akar persoalan.

Berdasarkan permasalahan di atas, kami para peneliti mencoba untuk mengali lebih dalam dalam terkait peran daerah dalam menimplementasikan program sebagai upaya perlindungan terhadap tindak kekerasan terhadap anak di dalam mewujukan kota layak anak.

\section{Metode Penelitian}

Penelitian ini tergolong penelitian hukum normatif dengan menggunakan sumber hukum primer yang terdiri dari peraturan perundangundangan berkenaan dengan kewenangan Pemerintah Daerah. Tipe penelitiannya adalah deskriptif eksplanatoris dengan pendekatan masalah yang digunakan adalah pendekatan normatif analitis substansi hukum. Bahan hukum primer dalam penelitian ini adalah Undang-Undang Nomor 23 Tahun 2014 Tentang Pemerintahan Daerah. Dan Undang-Undang Nomor 35 Tahun 2014 Tentang Perubahan Undang-Undang Nomor 23 Tahun 2002 Tentang Perlindungan Anak. Bahan hukum sekunder yang dipergunakan dalam penelitian ini diperoleh dari sumber pustaka berupa buku-buku atau literatur jurnal hukum, media cetak lainnya, media elektronik, yang ada kaitannya dengan masalah penelitian. Pengumpulan data yang dilakukan dalam penelitian ini adalah studi Kepustakaan. Undang-Undang Nomor 35 Tahun 2014

\footnotetext{
${ }^{1}$ Keputusan Presiden Nomor 36 Tahun 1990 tentang Pengesahan Convention On The Rights Of The Child (Konvensi Tentang Hak-Hak Anak)
} 
Tentang Perubahan Undang-Undang Nomor 23 Tahun 2002 Tentang Perlindungan Anak

\section{Hasil Dan Pembahasan}

\section{A. Peran Daerah Dalam Penanganan Tindak Kekerasan Terhadap Anak}

Berdasarkan Kamus Besar Bahasa Indonesia, otonomi adalah pola pemerintahan sendiri. Sedangkan otonomi daerah adalah hak, wewenang, dan kewajiban daerah untuk mengatur dan mengurus rumah tangganya sendiri sesuai dengan peraturan perundang-undangan yang berlaku². Berdasarkan Undang-Undang Nomor 23 Tahun 2014 Tentang Pemerintahan Daerah, definisi otonomi daerah sebagai berikut: "Otonomi daerah adalah hak, wewenang, dan kewajiban daerah otonom untuk mengatur dan mengurus sendiri urusan pemerintahan dan kepentingan masyarakat setempat dalam sistem Negara Kesatuan Republik Indonesia".

Pasal 18 Undang-Undang Dasar 1945 merupakan dasar hukum pembentukan Pemerintaha Daerah dan penyelenggaraan otonomi daerah dengan memberikan kewenangan yang luas, nyata dan bertanggungjawab kepada daerah. Dalam menentukan kewenangan yang dimiliki oleh daerah, berlaku teori residu, kewenangan daerah merupakan sisa dari semua kewenangan setelah dikurangi enam kewenangan yang dimiliki oleh pemerintah pusat. Dengan demikian berarti kewenangan yang dimiliki daerah tidak terhingga, sehingga setiap daerah dapat menyelenggarakan kewenangan.

Pada dasarnya pembentukan daerah dimaksudkan untuk meningkatkan kemandirian pada daerah serta sebagai pelayanan publik guna mempercepat terwujudnya kesejahteraan masyarakat disamping sebagai sarana pendidikan politik di daerah. Dalam penyelenggaraan urusan pemerintahan dilaksanakan berdasarkan asas desentralisasi, asas dekonsentrasi, dan asas tugas pembantuan ${ }^{3}$

Pasal 1 Angka 8 Undang-Undang Nomor 23 Tahun 2014 Tentang Pemerintahan Daerah menjelaskan bahwa asas desentralisasi adalah penyerahan urusan pemerintahan oleh pemerintah pusat kepada daerah otonom berdasarkan asas otonomi. Dalam asas ini daerah berhak untuk menjalankan segala urusan untuk mengatur dan mengurus sendiri urusan pemerintahan yang diberikan oleh pemerintah pusat namun masih dalam kerangka Negara Kesatuan Republik Indonesia.

Asas dekonsentrasi adalah pelimpahan sebagian urusan pemerintahan yang menjadi kewenangan pemerintah pusat kepada gubernur sebagai wakil pemerintah pusat, kepada instansi vertikal di wilayah tertentu, dan/atau kepada gubernur dan bupati/wali kota sebagai penanggung jawab urusan pemerintahan umum ${ }^{4}$ Maksudnya adalah pelimpahan wewenang pemerintahan yang sebenarnya kewenangan itu ada ditangan pemerintah pusat, yakni menyangkut penetapan strategi kebijakan dan pencapaian program kegiatannya, diberikan kepada gubernur atau instansi vertikal

\footnotetext{
2 Kamus Besar Bahasa Indonesia Departemen Pendididkan Nasioal ( Edisi Keempat), PT Gramedia Pustaka Utama, Jakarta, 2008, HIm.992

${ }^{3}$ Ketentuan Pasal 5 Ayat (4) Undang-Undang Nomor 23 Tahun 2014 Tentang Pemerintahan Daerah.

${ }^{4}$ Ketentuan Pasal 1 Angka 9 Undang-Undang Nomor 23 Tahun 2014 Tentang Pemerintahan Daerah.
} 
didaerah berdasarkan arahan kebijaksanaan umum dari pemerintah pusat, sedangkan sektor pembiayaannya tetap dilaksanakan oleh pemerintah pusat ${ }^{4}$

Asas tugas pembantuan adalah penugasan dari pemerintah pusat kepada daerah otonom untuk melaksanakan sebagian urusan pemerintahan yang menjadi kewenangan pemerintah pusat atau dari pemerintah daerah provinsi kepada daerah kabupaten/kota untuk melaksanakan sebagian urusan pemerintahan yang menjadi kewenangan daerah provinsi $^{5}$

Peraturan daerah adalah peraturan daerah provinsi dan/atau peraturan daerah kabupaten/kota. Pengaturan tentang Peraturan Daerah tersebut tertera pada Pasal 236 sampai Pasal 245 Undang-Undang Nomor 23 Tahun 2014 tentang Pemerintahan Daerah, sedangkan pengaturan Peraturan Kepala Daerah tertera pada Pasal 246 sampai Pasal 248 Undang-Undang Nomor 23 Tahun 2014 Tentang Pemerintahan Daerah

Pemerintahan Daerah seperti tertuang didalam Pasal 1 angka 1 Undang Undang Nomor 23 Tahun 2014 Tentang Pemerintahan Daerah, adalah penyelengaraan urusan pemerintahan oleh Pemerintah Daerah dan Dewan Perwakilan Rakyat menurut asas otonomi dan tugas pembantuan dengan prinsip otonomi seluas luasnya dalam sistem dan prinsip Negara Kesatuan Republik Indonesia sebagaimana dimaksud dalam Undang-Undang Dasar Negara Republik Indonesia Tahun $1945^{6}$

Regulasi tentang perlindungan anak ini diperbaharui lagi dengan Undang Undang nomor 53 Tahun 2014 Tentang Perubahan Undang-Undang nomor 23 Tahun 2002 tentang Perlindungan Anak. Bagian Kedua Kewajiban dan Tanggung Jawab Negara, Pemerintah, dan Pemerintah Daerah. di mana dalam Ketentuan Pasal 21 sampai dengan pasal 24 yang sebagian di ubah dan di tambah yang di mana menekankan peran pemerintah daerah harus lebih aktif lagi untuk melindungi dan memenuhi perlindugan anak. Pasal 21 (1) yang mana di sebutkan

Negara, Pemerintah, dan Pemerintah Daerah berkewajiban dan bertanggung jawab menghormati pemenuhan Hak Anak tanpa membedakan suku, agama, ras, golongan, jenis kelamin, etnik, budaya dan bahasa, status hukum, urutan kelahiran, dan kondisi fisik dan/atau mental.

Didalam Pasal 1 angka 12 dan 19 Undang-undang Nomor 35 Tahun 2014 Tentang Perubahan Atas Undang-Undang Nomor 23 Tahun 2004 Tentang Perlindungan Anak (UU PA) menjelaskan bahwa

Hak Anak adalah bagian dari hak asasi manusia (HAM) yang wajib dijamin, dilindungi, dan dipenuhi oleh Orang Tua, Keluarga, Masyarakat, Negara, Pemerintah, dan Pemerintah Daerah. Pemerintah Daerah disini adalah Gubernur, Bupati dan Walikota serta perangkat daerah sebagai unsur penyelengara pemerintahan

Hal diatas secara tegas menjelaskan bagaimana kewajiban dari Pemerintah Daerah untuk melindungi hak-hak anak terutama didalam perkembangannya menuju

\footnotetext{
5 Sunarno Siswanto, Hukum Pemerintahan Daerah di Indonesia, Sinar Grafika, Jakarta, hlm. 7-8

${ }^{6}$ Didalam UPA menjelaskan bahwa Pemerintah daerah disini diartikan bahwa sesuai Pasal 1 angka (18), bahwa Pemerintah Daerah adalah gubernur, bupati, dan walikota serta perangkat daerah sebagai unsur penyelenggara pemerintahan.
} 
dewasa, agar kelak menjadi orang yang berguna bagi Keluarga, Masyarakat, Pemerintah Daerah dan Negara. Seperti bunyi pasal 20 UU PA bahwa Negara, Pemerintah, Pemerintah Daerah, Masyarakat, Keluarga dan Orang Tua atau Wali berkewajiban dan bertanggung jawab terhadap penyelangaraan perlindungan anak.

Untuk menjamin pemenuhan Hak Anak sebagaimana dimaksud pada ayat (1), Pemerintah berkewajiban dan bertanggung jawab dalam merumuskan dan melaksanakan kebijakan di bidang penyelenggaraan Perlindungan Anak.

Prinsip-prinsip Perlindungan Anak yang wajib untuk dilindungi dan dijalankan oleh Pemerintah Darerah sesuai amanat dari UU PA, adalah ${ }^{7}$ :

a. Anak tidak dapat berjuang sendiri, salah satu prinsip yang digunakan dalam perlindungan anak adalah: anak itu adalah modal utama kelansungan hidup manusia, bangsa, dan keluarga, untuk itu hak-haknya harus dilindungi. Anak tidak dapat melindungi sendiri hak-haknya, banyak pihak yang mempengaruhi kehidupannya.

b. Kepentingan terbaik anak (the best interest of the child), agar perlindungan anak dapat diselenggarakan dengan baik, dianut prinsip yang menyatakan bahwa kepentingan terbaik anak harus dipandang sebagai of paramount importence (memperoleh prioritas tertinggi) dalam setiap keputusan menyangkut anak. Tanpa prinsip ini perjuangan untuk melindungi anak akan mengalami banyak batu sandungan.

c. Ancangan daur kehidupan (life-circle approach), perlindungan anak mengacu pada persamaan pada pemahaman bahwa perlindungan anak harus dimulai sejak dini dan terus menerus. Janin yang berada dalam kandungan perlu dilindungi dengan gizi termasuk yodium dan kalsium yang baik melalui ibunya. Jika ia telah lahir, maka diperlukan air susu ibu (ASI) dan pelayanan kesehatan primer dengan memberikan pelayanan imunisasi dan lain-lain, sehingga anak terbebas dari berbagai mungkin kecacacatan dan penyakit.

d. Lintas Sektoral, nasib anak tergantung dari berbagai faktor, baik yang makro maupun mikro, yang lansung maupun tidak lansung. Kemiskinan, perencanaan kota dan segala penggusuran, sistem pendidikan yang menekankan hafalan dan bahan-bahan yang tidak relevan, komunitas yang penuh dengan ketidakadilan, dan sebagainya dapat ditangani oleh sector, terlebih keluarga atau anak itu sendiri. Perlindungan terhadap anak adalah perjuangan yang membutuhkan sumbagan semua orang di semua tingkatan.

\section{Bagaimana Program Pemerintah Daerah dalam penanganan Tindak Kekerasan Terhadap Anak}

Program adalah unsur pertama yang harus ada demi terciptanya suatu kegiatan. Di dalam program dibuat beberapa aspek, disebutkan bahwa di dalam setiap program dijelaskan mengenai ${ }^{8}$

\footnotetext{
${ }^{7}$ Maidin Gultom, 2012, Perlindungan Hukum Terhadap Anak dan Perempuan, Refika Aditama, Bandung hlm. 71-72.
} 
1. Tujuan kegiatan yang akan dicapai.

2. Kegiatan yang diambil dalam mencapai tujuan.

3. Aturan yang harus dipegang dan prosedur yang harus dilalui.

4. Perkiraan anggaran yang dibutuhkan.

5. Strategi pelaksanaan.

Melalui program maka segala bentuk rencana akan lebih terorganisir dan lebih mudah untuk diopersionalkan. Hal ini sesuai dengan pengertian program yang diuraikan.

"A programme is collection of interrelated project designed to harmonize and integrated various action an activities for achieving averral policy abjectives" (suatu program adalah kumpulan proyek-proyek yang berhubungan telah dirancang untuk melaksanakan kegiatan-kegiatan yang harmonis dan secara integraft untuk mencapai sasaran kebijaksanaan tersebut secara keseluruhan.

Menurut Charles O. Jones, pengertian program adalah cara yang disahkan untuk mencapai tujuan, beberapa karakteristik tertentu yang dapat membantu seseorang untuk mengindentifikasi suatu aktivitas sebagai program atau tidak yaitu:

1. Program cenderung membutuhkan staf, misalnya untuk melaksanakan atau sebagai pelaku program Penangana Tindak Kekerasan Terhadap Anak

2. Program biasanya memiliki anggaran tersendiri, program kadang biasanya juga diidentifikasikan melalui anggaran.

3. Program memiliki identitas sendiri, yang bila berjalan secara efektif dapat diakui oleh publik.

Program terbaik didunia adalah program yang didasarkan pada model teoritis yang jelas, yakni: sebelum menentukan masalah sosial yang ingin diatasi dan memulai melakukan intervensi, maka sebelumnya harus ada pemikiran yang serius terhadap bagaimana dan mengapa masalah itu terjadi dan apa yang menjadi solusi terbaik (Jones, 1996:295).

Tanpa kebijakan, program dan pelayanan sosial yang tepat, dengan didukung dana, sarana, prasarana serta tenaga pelaksana yang memadai, masalah tersebut akan berdampak negatif terhadap perkembangan masyarakat dimasa depan khususnya anak, persoalan yang lain akan muncul jika program-program tidak menyentuh semua aspek kehidupan.

Adapun program-program Pemerintah Daerah yang mana dalam hal ini melalui Dinas Pengendalian Penduduk, Keluarga, Berencana. Pemberdayaan Perempuan Dan Perlindungan Anak Kabupaten Karimun' Tahun 2019 sebanyak 24 Program dan 216 Kegiatan dan Tujuh (7) terdiri dari Program dan Kegiatan yang berhubungan dengan perempuan dan anak, tentu kita mengapresiasi program-program yang diberikan pemerintah khususnya anak sebagai wujud dari bentuk perhatian Negara dan Pemerintah sebagaimana termaktub dalam Undang Undang nomor 53 Tahun 2014 Tentang Perubahan Undang-Undang nomor 23 Tahun 2002 Pasal 21 ayat (1)

\footnotetext{
${ }^{8}$ http://repository.usu.ac.id/bitstream/handle/123456789/29235/Chapter\%20II?sequence=3

${ }^{9}$ Musrembang ( Musyawarah Rencana Pembanguna ) Kabupaten Karimun 2018
} 
Negara, Pemerintah, dan Pemerintah Daerah berkewajiban dan bertanggung jawab menghormati pemenuhan Hak Anak tanpa membedakan suku, agama, ras, golongan, jenis kelamin, etnik, budaya dan bahasa, status hukum, urutan kelahiran, dan kondisi fisik dan/atau mental.

Tapi tentu saja dari sekian banyak Program yang akan dilaksanakan dengan berbagai kegiatan, tentu harus ada yang menjadi prioritas dan membuat langkah strategi dalam pencapaian perlindungan terhadap anak kalau melihat beberapa tiga (3) Tahun Terakhir tercatat pada Tahun 2015 selaku korban berjumlah 12 orang,sebagai saksi berjumlah 20 orang selaku tersangka 14 orang.

Tabel. 1 Gambaran ABH di Wilayah Hukum Karimun

\begin{tabular}{|l|l|l|l|l|}
\hline No & $\begin{array}{l}\text { Anak Berhadapan } \\
\text { Hukum }\end{array}$ & 2015 (kasus) & 2016 (kasus) & $\begin{array}{l}2017 \text { (kasus s/d } \\
\text { Agustus) }\end{array}$ \\
\hline 1 & Selaku Korban & 12 & 10 & 7 \\
\hline 2 & Selaku Saksi & 20 & 15 & 10 \\
\hline 3 & Selaku Tersangka & 14 & 20 & 11 \\
\hline
\end{tabular}

*berdasarkan data UPPA Polres Karimun

Tabel 2. Trend Kejahatan yang melibatkan anak sebagai pelaku

\begin{tabular}{|l|l|l|l|l|}
\hline No & Kasus & 2015 & 2016 & 2017 \\
\hline 1 & $\begin{array}{l}\text { Pencurian dengan } \\
\text { pemberatan }\end{array}$ & 4 & 5 & 7 \\
\hline 2 & Curanmor & 5 & 3 & 2 \\
\hline 3 & Cabul & 14 & 15 & 2 \\
\hline
\end{tabular}

*berdasarkan data UPPA Polres Karimun

\begin{tabular}{|l|l|l|l|l|}
\hline No & Kasus & $\begin{array}{l}2018(\text { Kasus s/d } \\
\text { Bulan Juni }\end{array}$ & & \\
\hline 1 & Selaku Korban cabul & 7 & & \\
\hline 2 & Pelaku Curanmor & 3 & & \\
\hline
\end{tabular}

\begin{tabular}{|l|l|l|l|l|}
\hline No & Kasus & $\begin{array}{l}\text { 2019 ( Kasus s/d } \\
\text { Bulan September }\end{array}$ & & \\
\hline 1 & Selaku Korban cabul & 10 & & \\
\hline 2 & Kekerasan terhadap anak & 1 & & \\
\hline 3 & Cabul & 1 & & \\
\hline
\end{tabular}

Dengan masih maraknya kejahatan yang berpotensi mengancam anak-anak, mengindikasikan bahwa penegakan hukum terhadap Undang-Undang Perlindungan Anak di Indonesia masih terbilang belum maksimal. Penguatan peran dari daerah menjadi kata kunci, tentu tidak sekedar membaca amanat undang-undang yang sudah memberikan perlindungan yang cukup bagi perlindungan anak, seperti "Pasal 55 (1) 
Pemerintah dan Pemerintah Daerah wajib menyelenggarakan pemeliharaan, perawatan, dan rehabilitasi sosial Anak terlantar, baik di dalam lembaga maupun di luar lembaga. Dan melakukan kerjasama dengan berbagai pihak, membentuk Komisi Perlindungan Anak Daerah yang bersifat independen yang diharapkan dapat mendukung Pemerintah dan Pemerintah Daerah dalam penyelenggaraan Perlindungan Anak

Membentuk Lembaga Penyelenggaraan Kesejahteraan Sosial Anak yang berhadapan dengan hukum (LKPS ABH) serta Lembaga Pembinaan Khusus Anak (LPKA), sera Perda tentang anak yang belum sepenuhnya menjawab persoalan anak yang menjadi PR bagi pemerintah daerah sampai saat ini yang sebenarnya sebagai tindakan yang bisa di lakukan baik sebagai Represif maupun sebagai bentuk tindakan preventif dan

Pemerintah daerah juga harus mampu bisa membaca kondisi-kondsisi yang real, mulai dari tingkat kemiskinan, tingkat pendidikan serta hal-hal yang memicu kekerasan terhadap anak harus di baca secara komprehensif, pemerintah daerah dalam menanganani tindak kekerasan terhadap, setiap program atau kegiatan yang di buat tentu harus benar-benar berdasarkan analisis dan kajian yang tepat terhadap persoalan kekerasan seksual di Indonesia khususnya Di berbagai daerah yang terjadi terhadap anak sehingga setiap program dan kegiatan mencapai titik sasarannya

seharusnya ada beberapa tempat yang menjadi perhatian serius bagi pemerintaah daerah yang indikasinya bisa memicu anak untuk di jadikan obyek kekerasan bahkan pelaku kekerasan itu sendiri, mengidentifikasi potensi, kapasitas, kerentanan, dan ancaman menjadi salah satu langkah untuk tidak terjadinya tindak kekerasan terhadap anak, serta beberapa kesiapan yang mendukung terkait penanganan kekerasan terhadap anak, karena tindak kekerasan terhadap anak sangat kompek persoalannya mulai dari tingkat kemiskinan, pendidikan lingkungan serta lemahnya peran daerah dalam melakukan tindakan preventif terhadap isu kekerasan terhadap anak

Undang-Undang Perlindungan Anak sudah beberapa kali mengalami beberapa perubahan, terakhir di Undangkan Nomor 1 Tahun 2016 dari beberapa pasal yang sempat menjadi perdebatan akhirnya masuk menjadi pasal baru, di satu sisi menjadi angin segar yang menegakkan perlindungan terhadap anak-anak, utamanya dalam menghadapi kekerasan dan pelecehan seksual yang kini tengah merebak di di berbagai daerah tidak terkecuali kabupaten karimun. Misalnya pelaksanaan hukuman mati bagi mereka yang mengikutsertakan anak dalam kejahatan narkoba dan pelaksanaan kebiri kimia bagi pelaku kejahatan seksual terhadap anak pada pasal 81A ayat 3. Serta beberapa pasal seperti hantu yang sangat mengerikan bagi pelaku kejahatan terhadap anak dan masyarakat awam. Pemberatan sanksi ini lebih dianggap mampu memberikan efek jera. Tidak sekedar itu, Undang-Undang Perlindungan Anak mengatur pula upayaupaya preventif sebagai langkah meminimalisir agar tidak sampai terjadi kejahatan.Namun tampaknya implementasi Undang-Undang Perlindungan Anak bukanlah hal mudah dan sederhana. Karena apabila ditilik lebih dalam ternyata UndangUndang ini tidak sepenuhnya menunjukkan pembelaan terhadap anak itu sendiri. Sebagai aturan yang bertujuan melindungi hak asasi anak, Undang-Undang Nomor 17 
Tahun 2016 justru terkesan fokus pada penanganan "instan" pelaku kejahatan terhadap anak saja. Penanganan instan ini maksudnya, kita mengkhawatirkan bahwa aparat penegak hukum hanya sebatas menjatuhkan sanksi pokok saja apakah akan di hukum penjara, hukuman mati atau kebiri (pelaku kejahatan seksual). Tentu juga menjadi pertanyaan kita apakah memang sudah ada sebuah penelitian yang benar-benar bisa menyatakan apakah tindak reperesif bisa membuat tingkat kejahatan terhadap seseorang dalam hal ini anak bisa menurunkan tingkat kejahatan seksual tersebut. Terutama di daerah yang mana aparat penegakan hukum belum banyak mengetahui tentang karakterisik / konsep tentang anak, memiliki rasa kecintaan kepada anak, memahami dunia anak dan mampu mendekati anak dengan tepat. Serta Tanpa adanya penjelasan yang pasti akan hak-hak anak sebagai korban kejahatan apakah anak mendapatkan ganti rugi, mendapatkan fasilitas pendampingan atau pengawasan serta hal-hal lain yang berhubungan dengan kepentingan anak.

\section{Kesimpulan}

Anak adalah Aset penerus bangsa dan generasi penerus dari orang tua dan negaranya, tanpa ada perhatian yang komprehensif dan berkontiniu dari Negara dan daerah itu sendiri, Pelaku kekerasan seksual masih mengancam masyarakat meski ancaman hukum telah ada di dalam Undang-Undang Nomor 35 tahun 2015 tentang Perubahan Atas Undang-Undang Nomor 23 tahun 2002 tentang Perlindungan Anak, terakhir Presiden telah mengeluarkan Peraturan Pemerintah Pengganti Undang-Undang Nomor 1 tahun 2016 tentang Perubahan Kedua atas Undang-Undang Nomor 23 tahun 2002 tentang Perlindungan Anak, dan akhirnya di undangkan pada tahun 2016. Walaupun Pro-kontra hukuman kebiri muncul setelah pemerintah berencana menerapkan hukuman kebiri kepada pelaku pedofilia. Pihak yang pro berargumen hukuman kebiri diperlukan karena kasus kekerasan seksual sudah dalam tahap darurat. Sementara pihak yang kontra menolak hukuman kebiri berdasarkan beberapa argumen. Ada yang menolak karena mempertanyakan efektivitasnya dalam menimbulkan efek jera dan itu, satu sisi kita apresiasi sebagai bentuk keseriusan dari negara,tp bagi penulis tindakan preventif dari daerah itu sendiri yang menjadi poin penting.

\section{Daftar Pustaka}

Kamus Besar Bahasa Indonesia Departemen Pendididkan Nasioal ( Edisi Keempat), PT Gramedia Pustaka Utama,

Laurensius Arliman Jurnal ilmu Hukum, volume 7, Nomor 2, Oktober, 2016

Maidin Gultom, 2012, Perlindungan Hukum Terhadap Anak dan Perempuan, Refika Aditama, Bandung

Suyanto. 2000. Refleksi dan Reformasi Pendidikan di Indonesia Memasuki Milenium III. Yogyakarta: Adicita.

Sokenato, Soerjono. 1987. Sosiologi suatu Pengantar

Sunarno Unarso Siswanto Hukm Pemerintah Daerah di Indonesia, Sinar Grafika, Jakarta 
Undang-Undang Nomor 23 Tahun 2014 Tentang Pemerintahan Daerah Undang-Undang Nomor 35 Tahun 2014 Tentang Perubahan Undang-Undang Nomor 23 Tahun 2002 Tentang Perlindungan Anak. 